\title{
The Issue of Universality and Contemporary Ethiopian Fiction
}

\author{
Gopal Sharma
}

School of Language Studies and Journalism, Post Box No: 395, Wollega University, Ethiopia

\begin{abstract}
The Western critic often finds African fiction in English devoid of such universal elements as 'love' and its various manifestations. The African mind wishes to stop further discussion about 'universality'. The purpose of present research is to underline the fact that 'love' as a theme in African fiction is not conspicuous by its absence and even the fictional narratives written by the new comers in the field- The Ethiopian Fiction in English -is worth noting and appreciating in this regard. Starting from Sahle Sellassie Berhane Mariam and Dagnachew Worku to Meron Tekleberhan novelists of the day depict 'love' in all its aspects. They not only write to influence people and shape a better society but also cater to the tastes of the new generation to inculcate in them reading habits in a foreign language and to instill in them values necessary to survive in the expanding world.
\end{abstract}

\begin{tabular}{l} 
Article Information \\
\hline Article History: \\
Received : 29-04-2012 \\
Revised : 25-06-2012 \\
Accepted : 28-06-2012 \\
\hline Keywords: \\
Universality \\
Love \\
Ethiopian fiction \\
English \\
'Corresponding Author: \\
Gopal Sharma \\
E-mail: \\
prof.gopalsharma@gmail.com
\end{tabular}

\section{INTRODUCTION}

The concept of universality in literature is one of the areas of interest to Post -Colonial writers and critics. The western critics often wish to judge every work using Arnolidan 'touchstone'. There has been a view that what Shakespeare, Milton, Dante or Goethe and their ilk wrote is 'universal' and 'eternal' and those who did not or do not touch those universal conditions are not universal in letter and spirit. What Kalidasa, Ghalib, Firdousi and other writers said is universal in character only when it matches with theirs. That is why it is often said that 'Kalidasa is the Shakespeare of Sanskrit literature' but no one in the west ever said that 'Shakespeare is the Kalidasa of English literature'. The teaching of the British English literature by the colonial masters to their native subjects was also to inculcate in them those 'universal values' that they thought were 'universal'. The other literatures, as said by Macaulay were just not even equal to be kept in a corner of the European literary shelf, and had been often considered as Plato's cave where

'ignorant rustics were chained men...counting the shadows of subterranean fires'.

\section{The Two Extreme View Points}

When we study how the western critics view Africa in general and African Writing in English in particular we feel as if the continent is kept somehow outside of History and that 'Africa is no historical part of the world'. One can find the words of the great German philosopher Hegel (1892) in 'The Philosophy of History' as the guiding philosophy for the average western critic:

Africa proper, as far as History goes back, has remained for all purposes of connection with the rest of the world-shut up; it is the gold land compressed within it. The land of childhood, which lying beyond the days of self -conscious history, is enveloped in the dark mantle of night ...what we properly understand as Africa is the unhistorical , underdeveloped spirit, still involved in the conditions of mere nature and which had to be presented here only as on the threshold of the World history...

This kind of Western thinking and 'Image of Africa' sometimes keeps African literature also out of academic discussion and even after the 
overwhelming interest in African Writing in English this is what Charles Larson (1971) tells in his book "The Emergence of African Novel" in a chapter devoted to Laurie Peter's novels:

That it is set in Africa appears to the accidental, for, except for a few comments at the beginning, Peter's story might just as easily take place in the southern part of the United States or in the southern regions of France or Italy. If a few names of characters and places were changed one would indeed feel that this was an American novel. In short, Peter's novel is universal.

The critic Charles Larson (1973) taught English literature to High School students in Nigeria in 1962 and found that their 'experience of literature' and 'understanding' is not 'universal' in character:

I can think of no contemporary African novel in which the central plot or theme can be called a love story, no African novel in which the plot lined progresses because of the hero's attempt to acquire a mate, no African novel in which seduction is the major goal, no African novel in which the faith of the lovers becomes the most significant elements in the story. No African novel works in this way because love as a theme in western literary sense is simply missing. Romantic love seduction, sex, these are not the subject of African fiction. In fact, in most contemporary African novels women play minor parts. The stories are concerned for the most part with a masculine word.

Hurt, dejected and pained critics and writers thought that this kind of thinking should be better stopped because only when the criticism is constructive, one can benefit from it. Chinua Achebe, on behalf of several African writers and critics opines in an essay on "Colonial Criticism" (1988) that beating the African fiction with the stick made of the word 'universal' should be stopped forth with -in the nature of things the work of a western writer is automatically informed by universality. It is only others who must strain to achieve it. He recommends:

"I should like to see the word universal banned altogether from discussion of African literature until such a time as people cease to use it as synonym for the narrow, self serving parochialism of Europe until their horizons to include the entire world"

\section{The Middle Path}

Both the views are extreme and critical that is why I have quoted both at length, the celebrated critic and the writer, in detail because on the one hand I can give a number of examples and illustrations from African fiction where there is a love story in their sense, on the other hand I would not advocate and ask for any such ban on African literature or any other literature. This is the time when we should talk in the words of Narasimhaih (1978), about the literatures of English' and not 'the literature in English'. The solution lies in taking control of our own literary criticism. If 'love' is the most common theme in literature and the greatest love stories have no time and place then the African novel can't be untouched with the universal passion.

The novelist and critic Forster (1927) in his path- breaking study "Aspects of the Novel" clearly states that the main facts in human life are five: Birth, Food, Sleep, Love and Death. But he, as it should be, is of the opinion that love is not only what happens between a boy and a girl at first sight. He explains:

Some people say that sex is basic and underlines all these other loves --- love of friends, of god, of country. Others say that it is connected with them but literally, it is not their root. Others say that it is not connected at all. All I suggest is that we call whole bundle of emotions love and regard them as the fifth grate experience through which human being has to pass.

Perhaps one of the right views is to see love as the whole bundle of emotions and not just sex, seduction, sensation and wild passionate kisses. Once the critic extends his vision and includes love in its all aspects, he need not read dozens and dozens of novels; even a few novels from an "expanding circle", to use Kachru's term, country can give instances of love, the so called universal theme.

\section{The Ethiopian Fiction in English}

The Ethiopian literature in English, according to Zerihum Asfa (2011), is in its infancy and the "paucity of works of fiction and poetry is conspicuous". But there are a number of star performers. Sahle Sellassie, Daniache Worku, Negash Gebre Mariam, Heddis Aleamayehu, Nega Mezlekia, Fasil Yitbarek, Dinaw Mengistu, Mavi Asgedom, Abbie Gubegna \& Fikeremarkos Desta are some of the names worth mentioning. My purpose is not to familiarize you with the novels of each and every novelist to prove my point. I would like to mention just a few Ethiopian novels in English to show that there is plenty of love and such other things. Take for instance "Land of the Yellow Bull" (2003) by Fikeremarkos Desta. The novel is an out and out love story in which love triangle, seduction, sex, romance, longing and pain all are in abundance. In the 
novel women play major parts also. This story is mainly concerned with Charlotte Alfred and her experiences, romantic relationship with an indigenous people and the virgin nature of the land of the yellow bull (wakealpenon). The hero Delti Geldi, a renowned elder, lover of the beautiful women is unfamiliar with the ways of the so-called civilized outer-world. That is why he doesn't use any language of his "whirlwind romance" Other than the language of the heart:

Both Delti Geldi and Charlotte did not try to communicate in a common language for their whirlwind romance. The language barrier didn't buff them at all. Their natural feelings communicated through natures' code without any overlap. Finally; before bread bin, got cooled they switched on together and went to roast their favourite love sweets inside the forest cooker.

The side story of the Hamar girl Goity and her lover Kello Horra is also a wonderful medium to enter the lovers' intrigues. In fact the Hamar girls 'looking after their sorghum and maize fields' sing and pray to god to give them the ability to express their true love to their lovers:

Borjo,you the creator of Bankimaro

The source of the blessed rain and

The master of our breath...

Give us the best manifestations of love...

Goity, the village belle loves Delti, the Lion Heart. $\mathrm{He}$ is a lady-killer indeed!

The girls propagated their admiration 'Didn't I tell you' He deserves admiration of a hero, they said to each other. Even his age-mates who down- played his previous achievement and had an ambivalent attitude towards his courage by saying 'who is he after all' bowed to him in respect. The spark that lit the flame of fame spread all over the Hamar girls eulofised the hero in their songs. Delti Geldi's fame started to become more gigantic than the Buska mountain itself. His name glanced out of a clear blue sky.

Goity grew up listening such heroic stories from her father and loved him before she even saw him in person. When they met their love was the western love at first sight:

"Have we ever seen one another before? No, but my teenage mates I know a lot forest consummate in their love". This is just the first meeting between them when 'abruptly she leaned over and kissed him. His arms were around her. She was lost in his smooth chest. He kissed her also passionately. They kissed each other gently".
There are several descriptions in detail in which 'kiss' in one of the starting point of meeting, mating and love-making. The love between Kello and Goity, between Charlotte and Delti makes the story interesting and the efforts of the lovers to win each other is worth noticing. Kello wants Goity as 'he was thinking about a complicated romantic love act soon unfolding, a drama in which the actors had not yet started their love scenes.' The reader can find ample references of 'sex', graphic description of erotic love in such paragraphs as follows:

First ladies and men warmed up their muscles flexed and carried their souls to heights. Then the girls span in circles changing their tracks while the men pursued them... afterward men would pass their naked thighs beneath that of the girls and hugged them so they would feel the erection passing their crutches. This erotic contact produced an electric current and the generator and the operator pushed their way out of the dance stage to a nearby forest consummate in their love.... She was the one who unzipped her dress and took off her underwear before he gently swung her legs. He approached, they wrapped their arms around each other and he gently kissed her for a while. Then he lifted and carried her into a tree...

This is just one novel and as said by Forster (1927) that it is very easy for a novelist to use the theme of love to create and develop his characters. There are two reasons, according to him, why love even in good novels in so prominent. Firstly, when the novelist ceases to design his characters and begins to create them, love in any or all of its aspects become important in his mind. Secondly, love like death, is congenial to a novelist because it ends a book conveniently. He can make it permanency. The three novels before me Escape, the Letter, the Young Crusader, all are published in 2011. They follow roughly the same 'trick' to end the novel. Escape by Gebeyehu Ayele ends when Dagne and Mulu meet together after escaping the clutches of their traditional and orthodox families. The novel ends when both of them start hugging and kissing .The Young Crusader by Solomon Hailemariam also shows us the same scene:

"Sofia moved closer to Admasu. It seemed that she was looking at something in Admasu's eyes. Suddenly they started kissing each other. Both of them were trembling out of sheer bliss."

and the novel ends.

The Letter by Meron Tekleberhan is also a love story but with a difference. The love between a teen-aged girl Ruth and her absent father 
Amanuel is portrayed in a manner that the reader is charmed and bewitched. This is the novelist's maiden attempt and yet she is able to transport the readers with her into her fictional world. This novel too ends when the father writes and replies his daughter's letter:

I am willing to meet you whenever and wherever you, please. I have no business in this life but you. You are the hope I named my business after. It's for you! Everything in my life has been held together by this one hope of one day having you! I love you with all that I am!

The Western critic may not acknowledge the love between father and daughter, teacher and student, mother and son but that is also love. The kiss planted on the forehead by the brother is also a "kiss". For instance in Abbie Gubegna's novel "Defiance" (1975) there is love in abundance for the motherland and the father, who is the embodiment of patriotism. The love between father and daughter allows the daughter to sacrifice her 'virginity' and be raped by the colonial general. There is love when the lover persuades the beloved to sleep with the enemy to get her father released so that the father could serve the cause of the motherland:

As Aster and Berhie were walking down where the general had parked his car, a sudden and wild desire overcame Berhie, he felt himself at liberty now, to embrace and kiss Aster and to tell her his love for her. Her father is freed now. Her purity destroyed. Even the enemy is making love with her. Where's the treason if I make love with her... Aster wouldn't have had any objection to his aspiration if Berhie had been bold enough to tell her...."

A bunch of novels written by Ethiopian immigrants are replete with sexual and other such overtones. For example in the novel "The Texture of Dreams" (2005) the novelist Fasil Yikbarek portrays the love between a young Ethiopian Yosef and Helen. Despite the fact she has a boyfriend and does not want to be in relationship based on love except sexual partnership, Yosef loves her dearly. The novel ends with Helen's desire to reciprocate his feelings. Dinaw Mengistu's novel "The Beautiful Things that Heaven Bears" (2007) also a love story between Stephanos and Judith. The reader knows that the contemporary Ethiopian fiction in English is to present their concerns and problems first and then only try to depict a fictional world free from corruption, poverty, boredom, bondage and memories of coups and dictators. Love, romance, sex, kiss, seduction, and holding hands etc. are so natural in the modern world of media and internet, films and advertisement that no novelist can write anything worthwhile without these. These are the themes -dominant themes in modern contemporary Ethiopian fiction also. The novelists present both pleasures and pains of human existence. That is why one of the characters in Desta's novel says:

Feeling is something abstract and imaginary. Although human feelings could have a certain impact on the social environment, the social setting has also a strong influence on human emotion. To love or to be loved is so natural and nobody would escape from its trap."

\section{CONCLUSIONS}

Though the Ethiopian fiction in English is one of the lesser known participants in the multitude of the African fiction scene, yet the new breed of writers will certainly make a mark. What the African writers Series by Heinemann did years back, it should be done by local publishers. The young readership is eager to read. They are the universal characters too. That is why the Ethiopian novelists should be better advised to keep presenting their work. "Your readers are your best critics. Look at them only!"

\section{REFERENCES}

Achebe Chinua. (1988). Hopes and Impediments: Selected Essays 1965-1987. Doubleday, New York.

Ayele Gebeyehu. (2011). Escape. Code-Ethiopia, Addis Ababa.

Desta Fikermarkos. (2003). Land of the Yellow Bull. Harmony, Addis Ababa.

Forster, E.M. (1927). Aspects of the Novels. Penguin, London.

Gubegna Abbie. (1975). Defiance. Oxford University Press, Addis Ababa.

Hailemariam Solomon. (2011). The Young Crusader. Code-Ethiopia, Addis Ababa.

Hegel, G.W. (1892) and (1956). The Philosophy of History. Dover Publications, New York.

Lamming George. (1960). The Pleasures of Exile. Michael Joseph, London.

Larson Charles. (1971). The Emergence of African Fiction. Indiana University Press, Indianapolis.

Larson Charles. (1973). Heroic Ethnocentricism: The Idea of Universality in Literature. American Scholar 42-43.

Narasimhaiah, C. D. (1978). Awakened Conscience: Studies in Commonwealth Literature (ed.). Sterling, Delhi.

Tekleberhan Meron, (2011) The Letters. CodeEthiopia, Addis Ababa. 